\title{
Manganese(II) Oxidizing Bacteria as Whole-Cell Catalyst for $\beta$-Keto Ester Oxidation
}

\author{
Juan Guo ${ }^{1}$, Huan Guo ${ }^{1}$, Jin Liu ${ }^{1, *}$, Fangrui Zhong ${ }^{1}$ and Yuzhou $\mathrm{Wu}^{1,2, *(1)}$ \\ 1 Hubei Key Laboratory of Bioinorganic Chemistry and Materia Medica, School of Chemistry and Chemical \\ Engineering, Huazhong University of Science and Technology, Wuhan 430074, China; \\ guojuan0201@163.com (J.G.); d201980126@hust.edu.cn (H.G.); chemzfr@hust.edu.cn (F.Z.) \\ 2 Max Planck Institute for Polymer Research, Ackermannweg 10, 55128 Mainz, Germany \\ * Correspondence: liujinlj1987@163.com (J.L.); wuyuzhou@hust.edu.cn (Y.W.)
}

Received: 14 February 2020; Accepted: 24 February 2020; Published: 2 March 2020

\begin{abstract}
Manganese oxidizing bacteria can produce biogenic manganese oxides (BMO) on their cell surface and have been applied in the fields of agriculture, bioremediation, and drinking water treatment to remove toxic contaminants based on their remarkable chemical reactivity. Herein, we report for the first time the synthetic application of the manganese oxidizing bacteria, Pseudomonas putida MnB1 as a whole-cell biocatalyst for the effective oxidation of $\beta$-keto ester with excellent yield. Differing from known chemical protocols toward this transformation that generally necessitate the use of organic solvents, stoichiometric oxygenating agents and complex chemical catalysts, our strategy can accomplish it simply under aqueous and mild conditions with higher efficiency than that provided by chemical manganese oxides. Moreover, the live MnB1 bacteria are capable of continuous catalysis for this $\mathrm{C}-\mathrm{O}$ bond forming reaction for several cycles and remain proliferating, highlighting the favorable merits of this novel protocol for sustainable chemistry and green synthesis.
\end{abstract}

Keywords: Pseudomonas putida MnB1; biogenic manganese oxides; abiotic manganese oxides; $\alpha$-Hydroxy- $\beta$-keto esters; whole-cell biocatalysis

\section{Introduction}

Developing sustainable biocatalytic processes for chemical synthesis has attracted considerable attention due to the ever-increasing environment concerns [1-3]. Conventional chemical production provides organic compounds that fulfil fundamental demands of modern society in pharmaceutical, agricultural, material and other fields, however, often at the expense of environment pollution and energy consumption. As such, biocatalysis provides a more favorable alternative considering its merits such as high catalytic activity and selectivity, mild reaction conditions (physiological $\mathrm{pH}$ and temperature), and environmental credentials (enzymes, organic solvent-free medium) [4-6]. In particular, whole-cell biocatalysis possesses unique advantages and extraordinary attractiveness. First, enzymes inside cells are to some extent in a protected environment and therefore often more stable than their isolated counterparts [7]. Besides, whole-cell biocatalysis integrates the benefits of enzyme cascades in a bacterial system and the fast proliferation of a living microbe, thus being more energy efficient, sustainable and easily recyclable [8]. However, the whole-cell catalytic reactions necessitate fast transportation of non-toxic substrates across the cell envelope to contact the enzymes, which essentially limits the substrate scope and reaction rate [9]. Therefore, novel strategies to utilize microorganisms for useful organic transformations are demanded to broaden the application of whole-cell biocatalysis in sustainable synthesis of fine chemicals.

Manganese dioxide $\left(\mathrm{MnO}_{2}\right)$ is a classic oxidant in organic synthesis with broad substrate scope and high reaction selectivity, as seen in alcohol oxidation, aromatization, oxidative coupling, and 
thiol oxidation [10-14]. In nature, biogenic manganese oxides (BMO) produced by $\mathrm{Mn}(\mathrm{II})$ oxidizing bacteria is widely present in soil and sediment, which has been extensively studied as a chemical catalyst or oxidizing reagent to remove various organic pollutants [15-17]. Of note, the main content of $\mathrm{BMO}$ is $\mathrm{MnO}_{2}$, which was found to have even larger specific surface area and higher reactivity than chemically prepared equivalents $[18,19]$. BMO producing bacteria can be directly applied in the fields of agriculture, bioremediation, and drinking water treatment to remove toxic contaminants [20-23], exhibiting extraordinary advantages such as high efficiency, low cost and environmental safety. Moreover, since the BMO is produced on the surface of bacteria and even secretes to the environment, these microbes can catalyze reactions without requiring the cell uptake of substrates and thus might benefit the reaction kinetics. Despite remarkable advances in various fields, the use of $\mathrm{Mn}$ (II) oxidizing bacteria as a whole-cell catalyst for synthesizing fine chemicals has not been explored (Figure 1).

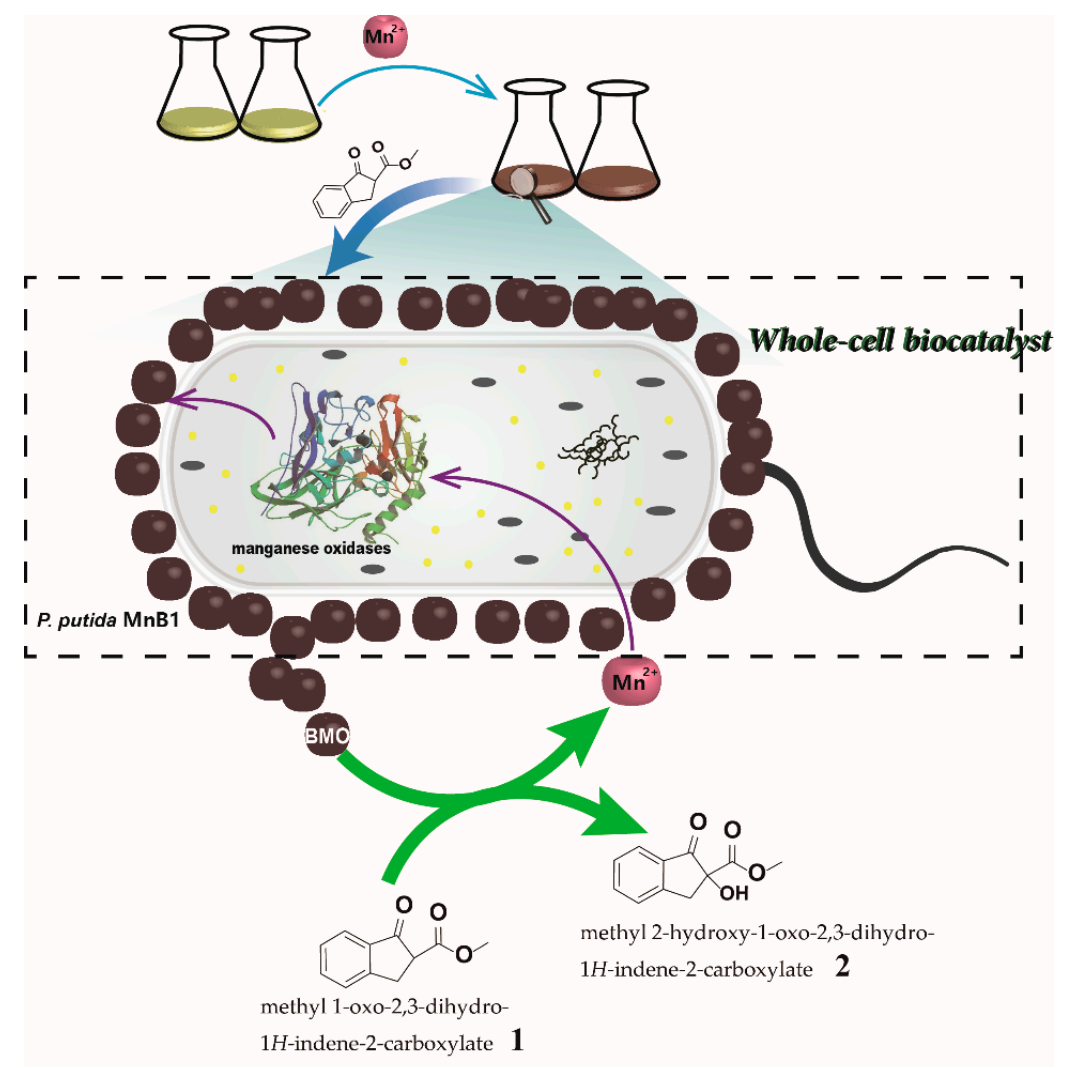

Figure 1. $\alpha$-hydroxy- $\beta$-keto ester (1) by whole-cell biocatalysis based on biogenic manganese oxides (BMO).

Pseudomonas putida MnB1, one of the most studied Mn(II) oxidizing bacteria, is ubiquitous in freshwater and soil, and can be cultivated even in complicated environments [20]. It would oxidize $\mathrm{Mn}(\mathrm{II})$ in liquid and solid media to Mn(IV) and accumulate BMO precipitates on the cell surface [24]. The robustness of P. putida MnB1 lays the groundwork for their prospective synthetic application as potential biocatalyst. To prove the concept of $\mathrm{Mn}$ (II) oxidizing bacteria whole-cell biocatalysis for organic synthesis, $\alpha$-hydroxylation of $\beta$-keto ester (1) (methyl 1-oxo-2,3-dihydro-1H-indene-2-carboxylate) was selected as model reaction. This reaction provides the most straightforward access to the $\alpha$-hydroxy- $\beta$-dicarbonyl, an intriguing moiety commonly found in various biologically active natural products, agrochemicals, and pharmaceuticals [25-27]. Notably, a number of chemical protocols are available to accomplish this oxidation to yield product 2 [28-33]. For instance, Lu et al. reported a Brønsted acid catalytic method with nitrosobenzene as the oxygen source [28], and Meng and co-workers documented a $\mathrm{Zr}(\mathrm{IV}) /$ organic peroxide system [30]. In general, the use of organic solvents and stoichiometric oxygenating agents were necessitated in conjunction with complex chemical 
catalysts, thus strongly compromising reaction economy and environmental friendliness. Herein, the BMO-based MnB1 catalyzed $\alpha$-hydroxylation of $\beta$-keto ester (1) can be successfully achieved in water with superior performance than that of chemically produced $\mathrm{MnO}_{2}$. Moreover, the live $\mathrm{MnB1}$ bacteria can be recycled with ease and remain proliferating, thus they are capable of continuously catalyzing the conversion of substrates. Therefore, this is a sustainable whole-cell biocatalytic system for efficient oxidation reaction that holds marked advantages for industrial applications due to the high efficiency, low cost and potential for flow chemistry.

\section{Results}

\subsection{Biogenic Manganese Oxides (BMO) Formation}

The reaction was firstly tested with lyophilized powder of the BMO mineralized MnB1 bacteria (noted as dry m-MnB1). To prepare it, MnB1 was cultured in Lept medium containing $1 \mathrm{mM} \mathrm{Mn}^{2+}$ for mineralization and the formation of BMO was observed by the production of dark brown sediments after $35 \mathrm{~h}$. The bacteria were continuously cultured for $5 \mathrm{~d}$ before harvesting by centrifugation and lyophilization. The Mn content in the dry $\mathrm{m}-\mathrm{MnB} 1$ was determined to be $28.8 \%$ according to inductively coupled plasma optical emission spectrometer (ICP-OES) (Figure S1). This result is consistent with the respective literature data $(18-30 \%)[18,19]$.

\subsection{Reactivity Comparison of the Dry m-MnB1 with Chemical Manganese Oxides (CMO) toward the Oxidation of $\beta$-Keto Ester}

\subsubsection{Solvent Effects on Oxidation Rate}

The dry m-MnB1 containing the BMO lyophilized together with MnB1 bacteria was mixed with $\beta$-keto ester (1) to test the oxidation reactivity. The performance of dry $\mathrm{m}-\mathrm{MnB1}$ was first compared with commercially available $\mathrm{MnO}_{2}$ powder $(\mathrm{CMO})$ in different media consisting of $\mathrm{H}_{2} \mathrm{O}$ and acetonitrile $(\mathrm{MeCN})$ under otherwise identical conditions. The Mn content was adjusted to be the same for both dry $\mathrm{m}-\mathrm{MnB} 1$ and CMO. The oxidized product was characterized by ${ }^{1} \mathrm{H}$ NMR spectroscopy (Figure S2). The yield of product 2 was determined by high performance liquid chromatography (HPLC) using comparably normalized standards (Figure S3). It was found that the mixed solvent system comprised of $90 \% \mathrm{H}_{2} \mathrm{O}$ and $10 \% \mathrm{MeCN}$ gave the highest yield of product 2 for both $\mathrm{BMO}$ and $\mathrm{CMO}(3 \mathrm{~h}, 94.1 \%$ and $54.7 \%$, respectively) (Figure 2a). Increasing the organic proportion was detrimental. For instance, the respective yield dropped to $21.8 \%$ and $12.7 \%$ in $\mathrm{MeCN} / \mathrm{H}_{2} \mathrm{O}$ (3:1). However, a small amount of $\mathrm{MeCN}$ was still necessary to dissolve the organic substrate. Nevertheless, the aqueous system adopted herein is much more favorable than known protocols exclusively using organic solvents. 


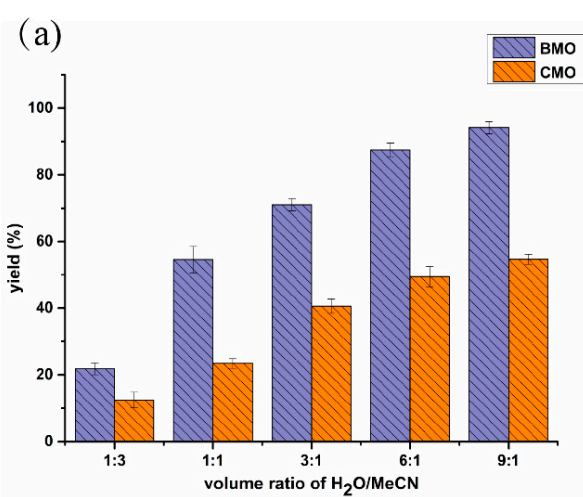

(c)

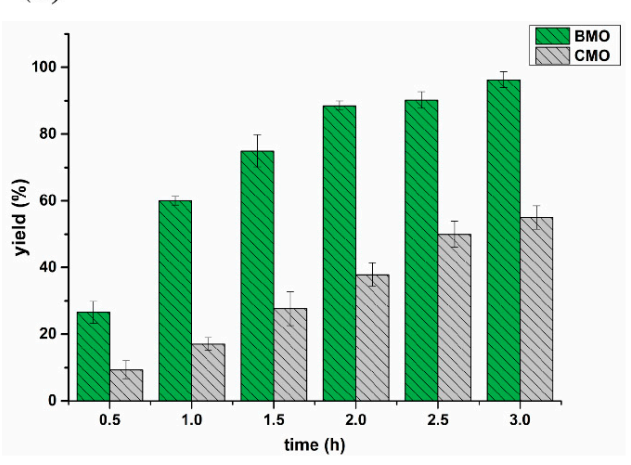

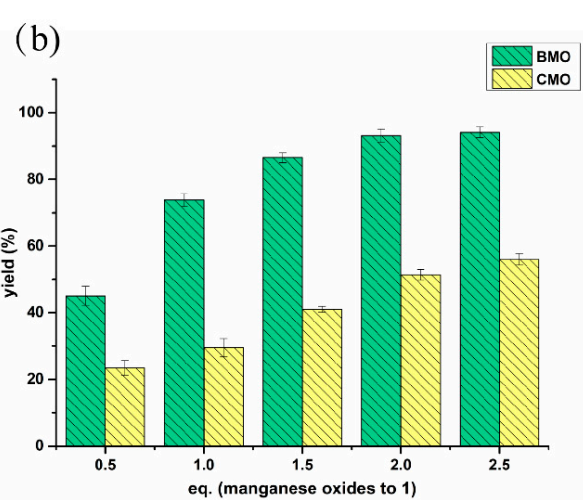

(d)

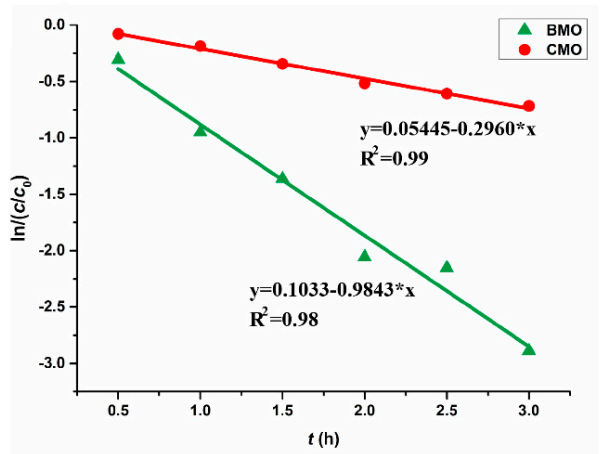

Figure 2. Comparing the synthesis of $\alpha$-hydroxy- $\beta$-keto ester by the BMO (biogenic manganese oxides) from dry m-MnB1 and CMO (chemical manganese oxides): (a) Effects of reaction media consisting of $\mathrm{H}_{2} \mathrm{O} / \mathrm{MeCN}$ with different ratios; (b) Effects of dosage of $\mathrm{BMO}$ and $\mathrm{CMO}$ in $\mathrm{H}_{2} \mathrm{O} / \mathrm{MeCN}(9: 1)$; (c) Correlation of yield of $\mathbf{2}$ with time; (d) Pseudo-first-order plots of $\alpha$-hydroxylation of $\beta$-keto Ester by $\mathrm{BMO}$ and $\mathrm{CMO}$ in the first $3 \mathrm{~h}$.

Notably, in all tested solvent conditions, BMO in dry m-MnB1 revealed significantly higher reactivity than $\mathrm{CMO}$, and almost 2 -fold higher yields were attainable in any given medium (Figure 2a). These results proved that the dry $\mathrm{m}-\mathrm{MnB1}$ possesses superior reactivity and selectivity than conventional CMO.

\subsubsection{Influence of Dosage of Manganese Oxides on Reaction Rate}

We subsequently explored the effects of dosage of manganese oxides on the oxidation of compound 1. A mixture of $\mathrm{H}_{2} \mathrm{O} / \mathrm{MeCN}$ (9:1) was employed as the reaction medium and the reaction time was set at $1 \mathrm{~h}$. As shown in Figure 2b, the ratio of manganese oxides to substrate 1 was found to significantly impact the oxidation process. As the dosage of $\mathrm{BMO}$ from dry m-MnB1 was increased from 0.5 eq. to 1.0 eq., the yield of 2 raised from $42 \%$ to $72 \%$. The outcome could be further improved to $91 \%$ with 2.0 eq of oxidant, and it became marginally higher with further addition of BMO. These results suggest 2.0 eq. of $\mathrm{BMO}$ is adequate. As the substrate 1 dissolved in the reaction medium was originally $5.0 \mathrm{mM}$, the factor limiting it from approaching full conversion might be the extremely low concentration at this point. Analogously, the same set of experiments were conducted with CMO. Although the conversion of substrate $\mathbf{1}$ was also evidently promoted along the addition of oxidant, the yield of $\mathbf{2}$ was constantly lower than BMO under identical conditions, for instance, as seen from $56 \%$ yield versus $93 \%$ yield with 2.5 eq. of manganese oxides. The results also back the notion that the BMO from dry $\mathrm{m}-\mathrm{MnB} 1$ is more efficient than the $\mathrm{CMO}$ for this oxidation reaction.

\subsubsection{Reaction Kinetics}

The kinetic parameters for both BMO and CMO mediated oxidation were studied (Figure 2c,d). It was found that $\alpha$-hydroxylation of substrate $\mathbf{1}$ with both BMO from dry m-MnB1 and CMO in 
the first $3 \mathrm{~h}$ followed Pseudo-first order kinetics, which were expressed as in equation (1), with C: concentration of $1(\mathrm{mmol} / \mathrm{L})$ at time $t(\mathrm{~h}), C_{0}$ : the initial concentration of $\mathbf{1}(\mathrm{mmol} / \mathrm{L})$, and $k$ : the rate constant $\left(\mathrm{h}^{-1}\right)$. By transforming Equation (1) into Equation (2),

$$
\begin{gathered}
C=C_{0} \cdot e^{-k \cdot t} \\
\ln \left(\frac{c}{c_{0}}\right)=-k \cdot t
\end{gathered}
$$

the rate constant can be calculated from the slope of the graph as depicted in Figure $2 \mathrm{~d}$. An average value for the rate constant $k$ of $0.9843 \pm 0.0215 \mathrm{~h}^{-1}$ was calculated with BMO from dry m-MnB1, while on the contrary, the rate constant of CMO was merely $0.296 \pm 0.0286 \mathrm{~h}^{-1}$ (Table 1). It is clear that the oxidation activity of the BMO from dry $\mathrm{m}-\mathrm{MnB1}$ is higher than CMO.

Table 1. Kinetic parameters of manganese oxides.

\begin{tabular}{ccc}
\hline Data & Dried BMO $^{\mathbf{1}}$ & CMO $^{\mathbf{2}}$ \\
\hline Rate constant $\left(k, \mathrm{~h}^{-1}\right)$ & $0.9843 \pm 0.0215$ & $0.296 \pm 0.0286$ \\
$\mathrm{R}^{2}$ & $0.97 \sim 0.98$ & $0.98 \sim 0.99$ \\
\hline${ }^{1}$ BMO: biogenic manganese oxides; ${ }^{2}$ CMO: chemical manganese oxides.
\end{tabular}

\subsection{Effects of $\beta$-Keto Ester 1 on Bacteria Growth}

In order to achieve the $\alpha$-hydroxylation of 1 by directly using live MnB1 bacteria, we moved on to investigate the influence substrate 1 on the growth of P. putida MnB1 at different concentrations. As illustrated in Figure 3a and Figure S4, the MnB1 growth profile did not deviate notably from the standard strain incubation in the presence of $5.0 \mathrm{mM}$ of substrate, while larger concentration $(10.0 \mathrm{mM})$ exhibited obvious toxicity. Further increase of concentration to 15.0 and $20.0 \mathrm{mM}$ both significantly suppressed the bacterial growth. Nevertheless, the bacteria were still proliferating even with $20.0 \mathrm{mM}$ substrate, highlighting the robustness of MnB1.

(a)

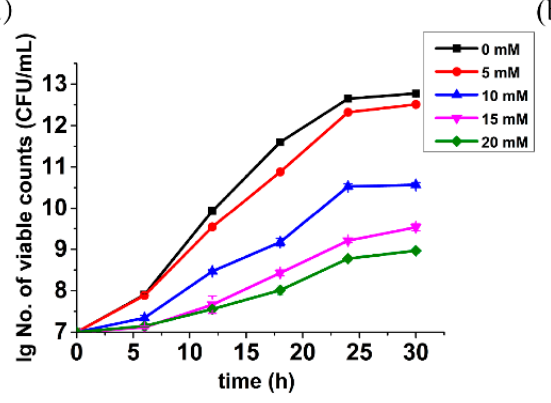

(b)

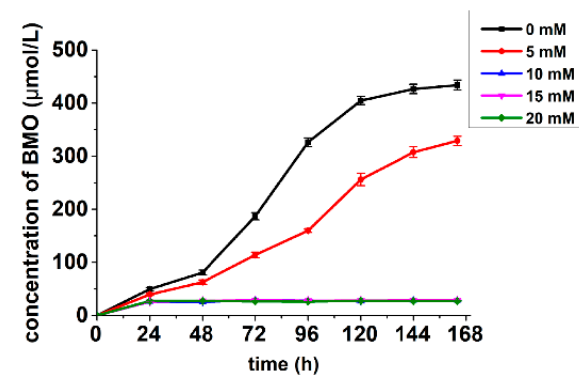

Figure 3. Effects of $\beta$-keto ester on the bacteria growth (a) measured by spread plate method and (b) the manganese mineralization; various colors refer to different concentrations of $\mathbf{1}$; CFU: colony forming units.

\subsection{Effects of $\beta$-Keto Ester 1 on Manganese Mineralization}

The effects of various concentrations of $\mathbf{1}$ on the manganese mineralization by the model strain were also probed. However, the manganese mineralization of MnB1 was found to be much more sensitive to substrate 1. A concentration of $5.0 \mathrm{mM}$ has already shown a significant inhibition on mineralization process, which was found to be completely repressed at $10.0 \mathrm{mM}$ or higher (Figure $3 \mathrm{~b}$ ). Since the generation of BMO by P. putida MnB1 was fundamentally accomplished via multicopper oxidase-catalyzed oxidation of $\mathrm{Mn}(\mathrm{II})$ into $\mathrm{Mn}(\mathrm{VI})$ in cell extracts within its active center with three $\mathrm{Cu}$ (II) sites [34-36], and the $\beta$-keto ester is known to chelate divalent metal ions, we speculate that 
compound 1 might potentially act as a multicopper oxidase inhibitor [37] to prohibit manganese oxide mineralization. Therefore, a maximum substrate concentration of $5.0 \mathrm{mM}$ was selected for the following whole-cell biocatalytic oxidation of substrate $\mathbf{1}$.

\subsection{Continuous Live MnB1 Catalyzed Synthesis of $\alpha$-Hydroxy- $\beta$-Keto Ester}

As the whole-cell catalysts have been previously demonstrated as a continuous and repeated-batch reaction system [38], herein we explored such potential of live MnB1 for $\alpha$-hydroxylation of 1 . The MnB1 bacteria were cultivated in Lept medium containing $1.0 \mathrm{mM} \mathrm{MnCl}_{2}$ until $0.45 \mathrm{mM} \mathrm{BMO}$ were formed according to leucoberbelin blue (LBB) test [39]. The substrate $\mathbf{1}$ was then directly added to the culture medium to reach the concentration of $5.0 \mathrm{mM}$. During the first round of synthesis, the reaction progress was monitored as shown in Figure 4a. The reaction rate was fast at the initial stage but slowed down with the BMO being consumed. The highest conversion could reach $92 \%$ after $24 \mathrm{~h}$ (Figure $4 \mathrm{~b}$ ). Afterwards, the MnB1 bacteria were recycled by centrifugation, and washed by PBS before re-culturing in a fresh medium. The same concentration of fresh substrate was added to the medium when the $\mathrm{BMO}$ concentration reached $0.45 \mathrm{mM}$ again. The yield of product 2 was consistently determined after $24 \mathrm{~h}$. Notably, in consecutive four cycles, virtually identical yield was attainable for each run, and all were over $90 \%$ (92\%, 91\%, 93\% and 94\% respectively, Figure 4c). These results clearly suggest that the MnB1-based whole-cells catalyst can be easily regenerated and recycled for continuous reactions, which is highly valuable for low cost and sustainable catalysis and flow chemistry.

(a)

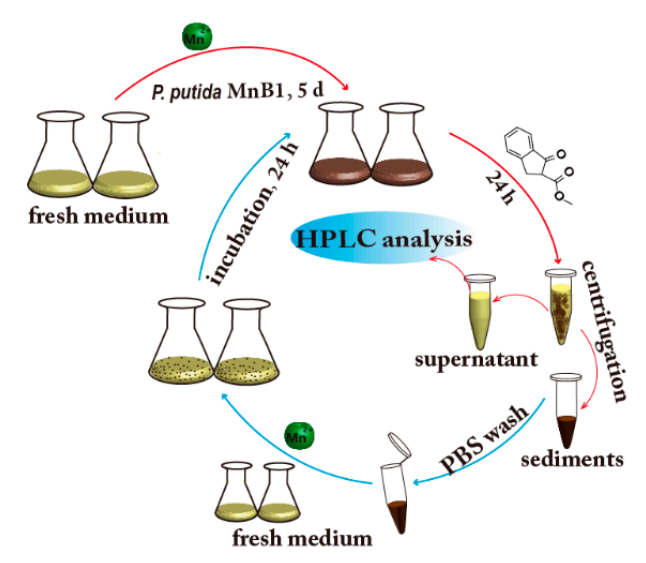

(b)

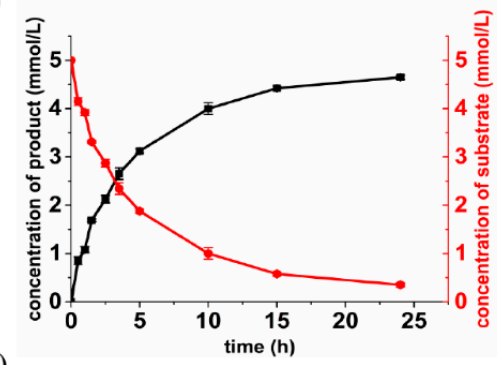

(c)

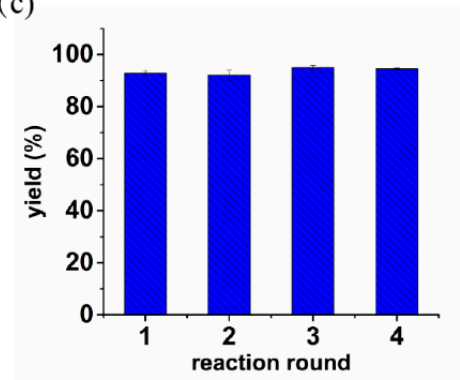

Figure 4. Synthesis of $\alpha$-hydroxy- $\beta$-keto ester by the whole cells based on the biogenic manganese oxides: (a) Schematic diagram of the recycling experiments; (b) Profile of substrate consumption and product formation; (c) Yield of product 2 in recycling reaction.

\section{Discussion}

Manganese oxides are known to be generated via oxidation of $\mathrm{Mn}^{2+}$ through both abiotic and biotic channels in the environment. Related reports indicated that the abiotic manganese oxidation pathway is much slower than biological processes, which are performed by a large variety of bacteria and fungi $[40,41]$. Here, we used P. putida MnB1 as the model strain to generate the BMO. Notably, P. putida MnB1 is ubiquitous in the freshwater and soil, and its optimal growth temperature is $26 \sim 30{ }^{\circ} \mathrm{C}$ [20], which indicates that the strains are readily available and can be cultivated even in complicated environments. Thus, the robustness of P. putida MnB1 lays the groundwork for the prospective industrial application of BMO. 
In recent years, $\mathrm{BMO}$ have received broad attention due to its marked redox reactivity, for instance, for the degradation of the organic pollutants, removal of heavy metal ions, etc. [42,43]. Although these processes involve various organic transformations, no rational synthesis of organic compounds with specific bond formation using BMO has been disclosed. In this study, we realized the synthesis of valuable $\alpha$-hydroxy- $\beta$-keto ester 2 by utilizing BMO as an oxidant to promote the highly selective $\mathrm{C}-\mathrm{O}$ bond formation event. Its superior performance than commercially available CMO highlights a strong capacity for synthetic oxidative reactions, and this is consistent with the previous studies on degradation applications [44]. In fact, oxidation of substrate 1 with BMO was a spot-to-spot process based on thin layer chromatography (TLC) analysis, and it was much faster and cleaner than that with CMO. Mechanistically, BMO produced by the P. putida MnB1 is known to contain larger inter-layer space and less structural Mn(III) than the CMO [45], thus providing larger specific surface areas [46]. We presume that these characteristics of BMO are beneficial to render defined interaction with substrates, and likely account for their better performance observed in our experiments.

Despite remarkable performance of isolated BMO for the oxidation of $\beta$-keto ester $\mathbf{1}$, we were further motivated to develop an environmentally friendly and efficient catalytic system by using whole-cell bacteria as a novel type of catalyst. However, tremendous challenges need to be taken into consideration, such as the compatibility with reaction media, the toxicity of substrate to cells and others [47]. Results of solvent optimization (Figure 2a) guided us to take mixture of $\mathrm{H}_{2} \mathrm{O}$ and $\mathrm{MeCN}$ as a suitable reaction medium. However, toxicity experiments showed that higher concentration $(10 \mathrm{mM})$ of substrate would drastically inhibit the mineralization function of bacteria (Figure $3 b)$. Jung [35] and Francis [34] independently concluded that the generation of BMO by P. putida MnB1 was fundamentally accomplished by multicopper oxidase, which catalytically oxidizes Mn(II) into $\mathrm{Mn}(\mathrm{VI})$ in cell extracts within its active center with three $\mathrm{Cu}$ (II) sites. This activity would get inhibited by heating or by treatment with a protease. The $\beta$-keto ester is known to chelate divalent metal ions, an essential component in the active site that interacts with amino acid residues of the enzyme. Therefore, this type of substrate might potentially act as a protein inhibitor [37]. We estimated that the higher concentration of $\beta$-keto ester 1 suppressed the manganese oxidizing partially due to the toxicity of substrate to the bacteria growth (Figure 3a and Figure S4), and this was probably a result of the impact of substrate on the activity of the multicopper oxidase. Based on these findings, we chose $5 \mathrm{mM}$ as an appropriate concentration of substrate to conduct the whole-cell biocatalysis. As the content of $\beta$-keto ester 1 was 5 -fold to $\mathrm{Mn}(\mathrm{II})$, the obtained $92 \%$ yield of product 2 clearly indicates $\mathrm{Mn}$ is operative in a catalytic manner, i.e., the regeneration of BMO by P. putida MnB1. Although a similar notion has been offered in the degradation of organic pollutants by Ko et al. [18], however, the recyclability of the bacteria for continuous catalysis has never been demonstrated.

In conclusion, we have realized the synthesis of valuable $\alpha$-hydroxy- $\beta$-keto ester (2) by utilizing $\mathrm{BMO}$ as an oxidant to promote the highly selective $\mathrm{C}-\mathrm{O}$ bond formation. Its superior performance than commercially available CMO highlights a strong capacity for synthetic oxidative reactions. Consecutive repeated-batch synthesis with recovered bacteria by the whole-cell catalytic system was achieved with consistently high levels of yield recorded [38]. Collectively, the whole-cell catalytic P. putida MnB1 with biogenic manganese oxides is highly robust, even amenable to organic transformation with somewhat toxic substrates. As Mn(IV) is extensively utilized in oxidative organic reactions, we anticipate that this efficient biological system is promising for the benign synthesis of various bioactive substances as well as bulk fine chemicals to meet the increasing demand for sustainable chemistry.

\section{Materials and Methods}

\subsection{Preparation of Freeze-Dried BMO}

The bacterial strain Pseudomonas putida MnB1 [American Type Culture Collection (ATCC) no. 23483] was cultured in the Lept medium ( $0.5 \mathrm{~g} / \mathrm{L}$ yeast extract (Ruji, Shanghai, China), $0.5 \mathrm{~g} / \mathrm{L}$ Casamino Acids (Coolaber, Beijing, China), 5 mM D(+)-glucose (Macklin, Shanghai, China), $10 \mathrm{mM}$ 
HEPES (N-2-hydroxyethylpiperazine- $N$ '-2-ethanesulfonic acid, pH 7.5, GBCBIO, Guangzhou, China), $0.48 \mathrm{mM} \mathrm{CaCl}_{2}$ (Macklin), $0.83 \mathrm{mM} \mathrm{MgSO}_{4}$ (Macklin), $3.7 \mu \mathrm{M} \mathrm{FeCl}_{3}$ (Macklin), and $1 \mathrm{~mL}$ of trace element solution $\left(10 \mathrm{mg} / \mathrm{L} \mathrm{CuSO}{ }_{4} \bullet 5 \mathrm{H}_{2} \mathrm{O}, 44 \mathrm{mg} / \mathrm{L} \mathrm{ZnSO}{ }_{4} \bullet 7 \mathrm{H}_{2} \mathrm{O}, 20 \mathrm{mg} \mathrm{CoCl}{ }_{2} \bullet 6 \mathrm{H}_{2} \mathrm{O}\right.$ and $13 \mathrm{mg} / \mathrm{L}$ $\mathrm{Na}_{2} \mathrm{MoO}_{4} \bullet 2 \mathrm{H}_{2} \mathrm{O}$, (Macklin)) containing $1 \mathrm{mM} \mathrm{MnCl}_{2}$ (Aladdin, Shanghai, China) at $30^{\circ} \mathrm{C}$ and shaken at $150 \mathrm{rpm}$ for $5 \mathrm{~d}$ [48]. The suspensions were centrifuged at $8000 \times \mathrm{g}$ for $20 \mathrm{~m}$ and the supernatant was discarded, sediments of bacteria and BMO were diluted three times with deionized water by means of centrifugation $(20 \mathrm{~m}$ at $8000 \times \mathrm{g})$, then the mixture of precipitates were collected for freeze-drying to obtain the dried BMO sample.

\subsection{Quantification of Freeze-Dried BMO by Inductive Coupled Plasma Optical Emission Spectrometry (ICP-OES)}

The $25 \mu \mathrm{g}$ dry m-MnB1 was treated with $200 \mu \mathrm{L} 90 \% \mathrm{HNO}_{3}$ overnight and heated at $70{ }^{\circ} \mathrm{C}$ for $30 \mathrm{~min}$, then was added $\mathrm{H}_{2} \mathrm{O}_{2}(30 \%, 200 \mu \mathrm{L})$. The resulting mixture was treated to evaporate at $200{ }^{\circ} \mathrm{C}$ for $1 \mathrm{~h}$ and then dissolved in deionized water to $4 \mathrm{~mL}$ solution to be measured by Inductive Coupled Plasma Optical Emission Spectrometry (ICP-OES 7000 Plus, ThermoFisher, Waltham, MA, USA) to quantify the amount of $\mathrm{Mn}^{2+}$. ICP-OES combined with a water cross-flow nebulizer and Ar was run as the carrier gas; auxiliary energy flow, coolant flow, and nebulizer flow were set as $0.7 \mathrm{~L} / \mathrm{min}$, $13.00 \mathrm{~L} / \mathrm{min}$, and $0.7 \mathrm{~L} / \mathrm{min}$, respectively. The analyses were calibrated by gravimetric standards with different concentrations (2 ppm, 4 ppm, 8 ppm, 16 and 32 ppm, respectively) that were measured before sample quantification.

\subsection{Synthesis of $\alpha$-Hydroxy- $\beta$-Keto Ester by the Dry $m-M n B 1$ and $C M O$}

A reaction mixture ( $400 \mu \mathrm{L}, \mathrm{MeCN}$ : $\left.\mathrm{H}_{2} \mathrm{O}=1: 1\right)$ containing $50 \mathrm{mM} \beta$-keto ester 1, $5.0 \mathrm{mg}$ dry $\mathrm{m}-\mathrm{MnB} 1$ or $1.75 \mathrm{mg} \mathrm{CMO}$ was shaken at $150 \mathrm{rpm}, 30^{\circ} \mathrm{C}$ for $3 \mathrm{~h}$. A control experiment was conducted without manganese oxide under otherwise identical reaction conditions. All reaction mixtures were monitored by TLC (hexanes/ethyl acetate $=3: 1$ ). Then, the resulting samples were centrifuged at $8000 \times g$ for $5 \mathrm{~m}$, supernatant was extracted with dichloromethane and evaporated under reduced pressure. The dried residues were purified by silica gel chromatography with hexanes/ethyl acetate (20:1-10:1) to get desired products for the NMR analysis. Finally, the purified samples were used as standards for the following HPLC detection.

\subsubsection{Optimization of the Reaction Medium}

The reaction mixtures $\left(400 \mu \mathrm{L}, \mathrm{MeCN}: \mathrm{H}_{2} \mathrm{O}=3: 1,1: 1,1: 3,1: 6\right.$ or 1:9) containing $50 \mathrm{mM} \beta$-keto ester (1) (Preparation of this substrate followed a known protocol [49]), $5.0 \mathrm{mg}$ dry m-MnB1 or $1.75 \mathrm{mg}$ $\mathrm{CMO}$ (Aladdin) were shaken at $150 \mathrm{rpm}, 30^{\circ} \mathrm{C}$ for $3 \mathrm{~h}$. The reaction samples were centrifuged at $8000 \times g$ for $5 \mathrm{~m}$ and supernatant was analyzed using HPLC to calculate the yield of oxidation product.

\subsubsection{Assays of Different Dosage of Manganese Oxides on the Oxidation Reaction}

Substrate $1(0.02 \mathrm{mmol})$ and dry m-MnB1/CMO (Chemical manganese oxides, Innochem, Beijing, China) $(0.01,0.02,0.03,0.04$, or $0.05 \mathrm{mmol})$ were added to test tubes and dissolved in MeCN $(40 \mu \mathrm{L})$ and $\mathrm{H}_{2} \mathrm{O}(360 \mu \mathrm{L})$. The reaction samples were stirred at $150 \mathrm{rpm}, 30{ }^{\circ} \mathrm{C}$ for $1.5 \mathrm{~h}$. Then, the reaction systems were centrifuged at $8000 \times g$ for $5 \mathrm{~m}$ and supernatants were analyzed using HPLC to obtain the yield of the oxidation product.

\subsubsection{Kinetic Measurements of Dry m-MnB1 and CMO}

To further compare the reaction efficiency of dry m-MnB1 and $\mathrm{CMO}$, kinetic parameters were detected. The reaction mixtures $(\mathbf{1}(0.02 \mathrm{mmol})$, dried-BMO/CMO $(0.02 \mathrm{mmol}), \mathrm{MeCN}(40 \mu \mathrm{L})$ and $\mathrm{H}_{2} \mathrm{O}(360 \mu \mathrm{L})$ were stirred at $150 \mathrm{rpm}, 30^{\circ} \mathrm{C}$, and the reaction progress was monitored by yield of the oxidation product. 


\subsection{Bioassays of Substrate $\beta$-Keto Ester Tolerance of Pseudomonas putida MnB1}

The bacterial strain Pseudomonas putida MnB1 was precultured overnight in LB medium (10 g/L tryptone, $10 \mathrm{~g} / \mathrm{L} \mathrm{NaCl}, 5 \mathrm{~g} / \mathrm{L}$ yeast extract) at $150 \mathrm{rpm}, 30^{\circ} \mathrm{C}$ and transferred into fresh Lept medium containing $1 \mathrm{mM} \mathrm{MnCl} 2$ and various concentrations of $1(0 \mathrm{mM}, 5 \mathrm{mM}, 10 \mathrm{mM}, 15$ and $20 \mathrm{mM}$, respectively). The colony forming units (CFU) were quantified by using the standard spread plate method [50] every $5 \mathrm{~h}$ until the generation of BMO. Simultaneously, the $\mathrm{OD}_{600 \mathrm{~nm}}$ level of bacteria was performed with microplate reader (3020-675, ThermoFisher).

\subsection{Investigation of the Effects of Substrate on Manganese Mineralization}

The oxidized Mn content generated in the suspension that was described in the Section 4.1 was measured at the indicated time points by using leucoberbelin blue (LBB, Sigma-Aldrich, St. Louis, MO, USA) method as illustrated by Krumbein [39]. With negligible modifications, bacteria culture (10 $\mu \mathrm{L})$ was added to $50 \mu \mathrm{L}$ LBB. After $15 \mathrm{~m}$ in the dark at room temperature, deposits were removed by centrifugation. $\mathrm{KMnO}_{4}$ was used as the standard to confirm the absorbance at $620 \mathrm{~nm}$ of supernatant.

\subsection{Continuous Biocatalytic Experiments by Whole Cells Based on BMO}

The bacterial strain Pseudomonas putida MnB1 was cultured in the Lept medium containing $1 \mathrm{mM}$ $\mathrm{MnCl}_{2}$ at $150 \mathrm{rpm}, 30^{\circ} \mathrm{C}$ for $5 \mathrm{~d}$ to generate the BMO. The concentration of BMO was quantified by LBB method before adding the $5 \mathrm{mM}$ substrate 1 to the medium. The mixture was then continued to shake at $150 \mathrm{rpm}, 30^{\circ} \mathrm{C}$ to get target product and the reaction progress was monitored by HPLC analysis. After the first-round reaction, the bacteria with $\mathrm{BMO}$ were collected by centrifugation and diluted three times with deionized water. The precipitates were added to fresh Lept medium containing $1 \mathrm{mM}$ $\mathrm{MnCl}_{2}$ to allow the continuous mineralization of manganese at $30{ }^{\circ} \mathrm{C}$ and $150 \mathrm{rpm}$. The mixture was used for the second-round reactions under comparable conditions when the concentration of $\mathrm{BMO}$ was similar with the first-round initial content. Four consecutive rounds of biocatalysis by whole-cell were conducted and yield of product in each round was measured. All procedures were performed under rigorous aseptic conditions.

\subsection{Methods and Conditions of HPLC Analysis}

For HPLC detection, all of the collected supernatant samples were filtered over a $0.22 \mu \mathrm{m}$ filter (Millipore, Billerica, MA, USA) and analyzed by HPLC system containing a LC-UV 100 absorbance detector (Wufeng, Shanghai, China). The compounds were separated on a reverse phase HPLC C18 column (C18 $250 \times 4.6 \mathrm{~mm}, 5 \mu \mathrm{m}$, Shodex, Tokyo, Japan) at a constant flow rate of $1.0 \mathrm{~mL} / \mathrm{min}$ and analysed by UV/Vis detection at $254 \mathrm{~nm}$. Solvent A was deionized water containing 5\% trifluoroacetic acid (TFA, Aladdin) and solvent B was acetonitrile containing 5\% TFA. A gradient from $0 \%$ to $70 \%$ solvent B was applied from 0 to $5 \mathrm{~min}$, the solvent B decreased $70 \%$ to $55 \%$ from 5 to $20 \mathrm{~m}$, then dropped to $5 \%$ during $5 \mathrm{~m}$. All analyses were calibrated by the absorption of substrate and product standards with different concentrations.

\subsection{Statistical Analysis}

All data were presented as means \pm standard deviation of three replicates. Statistical analysis was completed using SPSS 16.0 (Statistical Package for the Social Sciences, IBM Corp., Armonk, NY, USA).

Supplementary Materials: Supplementary materials can be found at http://www.mdpi.com/1422-0067/21/5/1709/ s1.

Author Contributions: Conceptualization, J.L., Y.W. and F.Z.; methodology, J.G., H.G. and J.L.; data curation, J.G. and J.L.; investigation, J.G. and H.G.; writing—original draft preparation, J.G.; writing—review and editing, Y.W. and F.Z.; supervision, Y.W. and F.Z.; funding acquisition, J.L. and Y.W. All authors have read and agreed to the published version of the manuscript. 
Funding: This research was funded by the National Key R\&D Program of China (2018YFA0903500), the China Postdoctoral Science Foundation funded project (2018M630849), the 1000 Young Talent Program of China, and Hubei Technological Innovation Project (2019ACA125).

Acknowledgments: We thank the Analytical and Testing Centre of HUST, Analytical and Testing Centre of School of Chemistry and Chemical Engineering (HUST), and Research Core Facilities for Life Sciences (HUST) for instrument support.

Conflicts of Interest: The authors declare no conflict of interest.

\section{Abbreviations}

$\begin{array}{ll}\text { BMO } & \text { Biogenic manganese oxide } \\ \text { CMO } & \text { Chemical manganese oxide } \\ \text { MeCN } & \text { Acetonitrile } \\ \text { CFU } & \text { Colony forming unit } \\ \text { ICP-OES } & \text { Inductive coupled plasma optical emission spectrometry } \\ \text { TFA } & \text { Trifluoroacetic acid }\end{array}$

\section{References}

1. Sheldon, R.A.; Brady, D. Broadening the scope of biocatalysis in sustainable organic synthesis. ChemSusChem 2019, 12, 2859-2881. [CrossRef] [PubMed]

2. Son, E.J.; Lee, Y.W.; Ko, J.W.; Park, C.B. Amorphous Carbon Nitride as a Robust Photocatalyst for Biocatalytic Solar-To-Chemical Conversion. ACS Sustain. Chem. Eng. 2018, 7, 2545-2552. [CrossRef]

3. Yuan, H.; Liu, H.; Du, J.; Liu, K.; Wang, T.; Liu, L. Biocatalytic production of 2, 5-Furandicarboxylic acid: Recent advances and future perspectives. Appl. Microbiol. Biot. 2020, 104, 527-543. [CrossRef] [PubMed]

4. Sandoval, B.A.; Hyster, T.K. Emerging strategies for expanding the toolbox of enzymes in biocatalysis. Curr. Opin. Chem. Biol. 2020, 55, 45-51. [CrossRef]

5. Skellam, E. Strategies for engineering natural product biosynthesis in fungi. Trends Biotechnol. 2019, 37, 416-427. [CrossRef]

6. Woodley, J.M. New frontiers in biocatalysis for sustainable synthesis. Curr. Opin. Green Sustain. Chem. 2020, 21, 22-26. [CrossRef]

7. Akanuma, S.; Bessho, M.; Kimura, H.; Furukawa, R.; Yokobori, S.-I.; Yamagishi, A. Establishment of mesophilic-Like catalytic properties in a thermophilic enzyme without affecting its thermal stability. Sci. Rep. 2019, 9, 1-11. [CrossRef]

8. Hepworth, L.; France, S.; Hussain, S.; Both, P.; Turner, N.; Flitsch, S. De Novo Enzyme Cascades in Whole Cells for the Synthesis of Chiral Cyclic Amines. ACS Catal. 2017, 4, 2920-2925. [CrossRef]

9. Duetz, W.A.; Van Beilen, J.B.; Witholt, B. Using proteins in their natural environment: Potential and limitations of microbial whole-Cell hydroxylations in applied biocatalysis. Curr. Opin. Biotechnol. 2001, 12, 419-425. [CrossRef]

10. Liao, X.; Hou, J.; Wang, Y.; Zhang, H.; Sun, Y.; Li, X.; Tang, S.; Kato, K.; Yamauchi, M.; Jiang, Z. An active, selective, and stable manganese oxide-supported atomic Pd catalyst for aerobic oxidation of 5-hydroxymethylfurfural. Green Chem. 2019, 21. [CrossRef]

11. Miao, L.; Wang, J.; Zhang, P. Review on manganese dioxide for catalytic oxidation of airborne formaldehyde. Appl. Surf. Sci. 2019, 466, 441-453. [CrossRef]

12. Najafpour, M.M.; Renger, G.; Hołyńska, M.; Moghaddam, A.N.; Aro, E.-M.; Carpentier, R.; Nishihara, H.; Eaton-Rye, J.J.; Shen, J.-R.; Allakhverdiev, S.I. Manganese compounds as water-Oxidizing catalysts: From the natural water-Oxidizing complex to nanosized manganese oxide structures. Chem. Rev. 2016, 116, 2886-2936. [CrossRef] [PubMed]

13. Reidies, A.H. Manganese Compounds; Wiley-VCH Verlag GmbH \& Co. KGaA: Weinheim, Germany, 2000.

14. Yu, Q.; Fu, Y.; Huang, J.; Qin, J.; Zuo, H.; Wu, Y.; Zhong, F. Enantioselective Oxidative Phenol-Indole [3+ 2] Coupling Enabled by Biomimetic Mn (III)/Brønsted Acid Relay Catalysis. ACS Catal. 2019, 9, 7285-7291. [CrossRef]

15. Jiang, L.; Huang, C.; Chen, J.; Chen, X. Oxidative transformation of $17 \beta$-Estradiol by $\mathrm{MnO}_{2}$ in aqueous solution. Arch. Environ. Contam. Toxicol. 2009, 57, 221-229. [CrossRef] [PubMed] 
16. Wang, G.; Liu, Y.; Wu, M.; Zong, W.; Yi, X.; Zhan, J.; Liu, L.; Zhou, H. Coupling the phenolic oxidation capacities of a bacterial consortium and in situ-generated manganese oxides in a moving bed biofilm reactor (MBBR). Water Res. 2019, 166, 115047. [CrossRef]

17. Zhang, H.; Huang, C.-H. Oxidative transformation of triclosan and chlorophene by manganese oxides. Environ. Sci. Technol. 2003, 37, 2421-2430. [CrossRef]

18. Tran, T.N.; Kim, D.-G.; Ko, S.-O. Synergistic effects of Biogenic Manganese Oxide and Mn(II)-Oxidizing bacterium Pseudomonas putida strain MnB1 on the degradation of $17 \alpha$-Ethinylestradiol. J. Hazard. Mater. 2018, 344, 350-359. [CrossRef]

19. Zhou, D.; Kim, D.-G.; Ko, S.-O. Heavy metal adsorption with biogenic manganese oxides generated by Pseudomonas putida strain MnB1. J. Eng. Chem. 2015, 24, 132-139. [CrossRef]

20. Caspi, R.; Tebo, B.M.; Haygood, M.G. c-Type Cytochromes and Manganese Oxidation in Pseudomonas putida MnB1. Appl. Environ. Microbiol. 1998, 64, 3549-3555. [CrossRef]

21. Martínez-Ruiz, E.B.; Cooper, M.; Fastner, J.; Szewzyk, U. Manganese-Oxidizing bacteria isolated from natural and technical systems remove cylindrospermopsin. Chemosphere 2020, 238, 124625. [CrossRef]

22. Su, J.; Deng, L.; Huang, L.; Guo, S.; Liu, F.; He, J. Catalytic oxidation of manganese (II) by multicopper oxidase CueO and characterization of the biogenic Mn oxide. Water Res. 2014, 56, 304-313. [CrossRef] [PubMed]

23. Wang, Y.-N.; Tsang, Y.F.; Wang, H.; Sun, Y.; Song, Y.; Pan, X.; Luo, S. Effective stabilization of arsenic in contaminated soils with biogenic manganese oxide (BMO) materials. Environ. Pollut. 2019. [CrossRef] [PubMed]

24. Villalobos, M.; Lanson, B.; Manceau, A.; Toner, B.; Sposito, G. Structural model for the biogenic Mn oxide produced by Pseudomonas putida. Am. Mineral. 2006, 91, 489-502. [CrossRef]

25. Kimura, M. Recent topics in the syntheses of $\beta$-keto carboxylic acids and the derivatives. Tetrahedron Lett. 2018, 59, 1295-1300. [CrossRef]

26. Ren, Q.; Huang, J.; Wang, L.; Li, W.; Liu, H.; Jiang, X.; Wang, J. Highly Efficient Assembly of 3-Hydroxy Oxindole Scaffold via a Catalytic Decarboxylative [1,2]-Addition Strategy. ACS Catal. 2012, 2, 2622-2625. [CrossRef]

27. Yang, F.; Zhao, J.; Tang, X.; Wu, Y.; Yu, Z.; Meng, Q. Visible Light-Induced Salan-Copper (II)-Catalyzed Enantioselective Aerobic $\alpha$-Hydroxylation of $\beta$-Keto Esters. Adv. Syn. Catal. 2019, 361, 1673-1677. [CrossRef]

28. Lu, M.; Zhu, D.; Lu, Y.; Zeng, X.; Tan, B.; Xu, Z.; Zhong, G. Chiral Brønsted acid-Catalyzed enantioselective $\alpha$-Hydroxylation of $\beta$-Dicarbonyl compounds. J. Am. Chem. Soc. 2009, 131, 4562-4563. [CrossRef]

29. Naganawa, Y.; Aoyama, T.; Kato, K.; Nishiyama, H. Cu (II)-Catalyzed Enantioselective $\alpha$-Hydroxylation and $\alpha$-Chlorination of $\beta$-Ketoesters with N, N, O-Tridentate Chiral Phenanthroline Ligand. Chem. Sel. 2016, 1, 1938-1942.

30. Yang, F.; Zhao, J.; Tang, X.; Zhou, G.; Song, W.; Meng, Q. Enantioselective $\alpha$-Hydroxylation by Modified Salen-Zirconium (IV)-Catalyzed Oxidation of $\beta$-Keto Esters. Organic Lett. 2017, 19, 448-451. [CrossRef]

31. Yin, X.P.; Zhu, L.; Zhou, J. Metal-Free Azidation of $\alpha$-Hydroxy Esters and $\alpha$-Hydroxy Ketones Using Azidotrimethylsilane. Adv. Syn. Catal. 2018, 360, 1116-1122. [CrossRef]

32. Zhang, Z.; Gao, X.; Yu, H.; Bi, J.; Zhang, G. Tandem Oxidative $\alpha$-Hydroxylation/ $\beta$-Acetalization Reaction of $\beta$-Ketoamides and Its Applications. ACS Omega 2017, 2, 7746-7754. [CrossRef] [PubMed]

33. Zou, L.; Wang, B.; Mu, H.; Zhang, H.; Song, Y.; Qu, J. Development of tartaric acid derived chiral guanidines and their application to catalytic enantioselective a-hydroxylation of b-dicarbonyl compounds. Org. Lett. 2013, 15, 3106-3109. [CrossRef] [PubMed]

34. Francis, C.A.; Tebo, B.M. cumA Multicopper Oxidase Genes from Diverse Mn (II)-Oxidizing and Non-Mn (II)-OxidizingPseudomonas Strains. Appl. Environ. Microbiol. 2001, 67, 4272-4278. [CrossRef] [PubMed]

35. Jung, W.K.; Schweisfurth, R. Manganese oxidation by an intracellular protein of a Pseudomonas species. J. Basic Microb. 2007, 19, 107-115.

36. Soldatova, A.V.; Romano, C.A.; Tao, L.; Stich, T.A.; Casey, W.H.; Britt, R.D.; Tebo, B.M.; Spiro, T.G. Mn (II) oxidation by the multicopper oxidase complex Mnx: A coordinated two-Stage Mn (II)/(III) and Mn (III)/(IV) mechanism. J. Am. Chem. Soc. 2017, 139, 11381-11391. [CrossRef]

37. Grobler, J.A.; Stillmock, K.; Hu, B.; Witmer, M.; Felock, P.; Espeseth, A.S.; Wolfe, A.; Egbertson, M.; Bourgeois, M.; Melamed, J. Diketo acid inhibitor mechanism and HIV-1 integrase: Implications for metal binding in the active site of phosphotransferase enzymes. Proc. Natl. Acad. Sci. USA 2002, 99, 6661-6666. [CrossRef] 
38. Ninh, P.H.; Honda, K.; Yokohigashi, Y.; Okano, K.; Omasa, T.; Ohtake, H. Development of a Continuous Bioconversion System Using a Thermophilic Whole-Cell Biocatalyst. Appl. Environ. Microbiol. 2013, 79, 1996-2001. [CrossRef]

39. Krumbein, W.E.; Altmann, H.J. A new method for the detection and enumeration of manganese oxidizing and reducing microorganisms. Helgoländer Wiss. Meeresunters. 1973, 25, 347-356. [CrossRef]

40. Hastings, D.; Emerson, S. Oxidation of manganese by spores of a marine bacillus: Kinetic and thermodynamic considerations. Geochim. et Cosmochim. Acta 1986, 50, 1819-1824. [CrossRef]

41. Das, A.P.; Sukla, L.B.; Pradhan, N.; Nayak, S. Manganese biomining: A review. Bioresour. Technol. 2011, 102, 7381-7387. [CrossRef]

42. Miyata, N.; Tani, Y.; Sakata, M.; Iwahori, K. Microbial manganese oxide formation and interaction with toxic metal ions. J. Biosci. Bioeng. 2007, 104, 1-8. [CrossRef] [PubMed]

43. Wang, R.; Wang, S.; Tai, Y.; Tao, R.; Dai, Y.; Guo, J.; Yang, Y.; Duan, S. Biogenic manganese oxides generated by green algae Desmodesmus sp. WR1 to improve bisphenol A removal. J. Hazard. Mater. 2017, 339, 310-319. [CrossRef] [PubMed]

44. Spiro, T.G.; Bargar, J.R.; Sposito, G.; Tebo, B.M. Bacteriogenic Manganese Oxides. Acc. Chem. Res. 2010, 43, 2-9. [CrossRef] [PubMed]

45. Liu, Y.; Li, Y.; Chen, N.; Ding, H.; Zhang, H.; Liu, F.; Yin, H.; Chu, S.; Wang, C.; Lu, A. Cu (II) sorption by biogenic birnessite produced by Pseudomonas putida strain MnB1: Structural differences from abiotic birnessite and its environmental implications. Cryst. Eng. Comm. 2018, 20, 1361-1374. [CrossRef]

46. Forrez, I.; Carballa, M.; Verbeken, K.; Vanhaecke, L.; Ternes, T.; Boon, N.; Verstraete, W. Diclofenac Oxidation by Biogenic Manganese Oxides. Environ. Sci. Technol. 2010, 44, 3449-3454. [CrossRef]

47. Florian, R. Whole-Cell based synthetic enzyme cascades-Light and shadow of a promising technology. Curr. Opin. Chem. Biol. 2019, 49, 84-90.

48. Boogerd, F.C.; de Vrind, J.P. Manganese oxidation by Leptothrix discophora. J. Bacteriol. 1987, 169, $489-494$. [CrossRef]

49. Gu, X.; Zhang, Y.; Xu, Z.-J.; Che, C.-M. Iron (III)-Salan complexes catalysed highly enantioselective fluorination and hydroxylation of $\beta$-keto esters and N-Boc oxindoles. Chem. Comm. 2014, 50, 7870-7873. [CrossRef]

50. Boukouvalas, D.T.; Prates, R.A.; Leal, C.R.L.; de Araújo, S.A. Automatic segmentation method for CFU counting in single plate-Serial dilution. Chemom. Intell. Lab. Syst. 2019, 195, 103889. [CrossRef] 